\title{
Borrowing for social security? Credit, asset-based welfare and the decline of the German savings regime
}

Journal of European Social Policy 2017, Vol. 27(5) 474-490 (c) The Author(s) 2017

Reprints and permissions: sagepub.co.uk/journalsPermissions.nav DOI: $10.1177 / 0958928717717658$ journals.sagepub.com/home/esp @SAGE

\author{
Daniel Mertens \\ Goethe University Frankfurt, Germany
}

\begin{abstract}
This article investigates the question to what extent Germany fits into the recent trend of credit-based social policy that has originated in Anglophone economies. In the course of the financial crisis and with its preceding increase in private indebtedness in mind, a growing number of scholars have argued that loans to households have become a central component of contemporary welfare states. Because of comprehensive savings-promotion schemes, high levels of public welfare provision and a low homeownership rate, the German welfare state conventionally figures as the paradigmatic counter case to this intensifying relation between welfare and finance. This article argues, to the contrary, that one can observe the rise of creditbased social policy in Germany due to the gradual erosion of savings promotion, the expansion of quasipublic loan schemes and the restructuring of the welfare state since the mid-1970s. Based on document and statistical analysis, the article evaluates reform trajectories in the field of pensions, education and healthcare to substantiate this claim. Within the current low-interest rate environment in the Eurozone, the developments combined might well challenge the traditional savings-oriented features of the German welfare state and its political economy.
\end{abstract}

\section{Keywords}

Asset-based welfare, debt, financialization, savings, social security, welfare regimes

\section{Introduction}

Finance is now a central conduit of risk shifting and social change. (Martin et al., 2008: 121)

When the credit bubbles burst in the late 2000s, many welfare states were confronted with immense challenges: pension and other investment funds had suddenly lost billions in their assets, while property prices and individual housing wealth collapsed, leaving millions of households across the advanced

\section{Corresponding author:}

Daniel Mertens, Goethe University Frankfurt, Institute of Political Science, Theodor-W.-Adorno-Platz 6, 60323Frankfurt am Main, Germany.

Email: mertens@soz.uni-frankfurt.de 
capitalist economies with gaps in their social security schemes (OECD, 2009). Since then foreclosures and over-indebtedness have shaken personal lives, even more so in countries where austerity constrained social budgets to work as automatic stabilizers. Against this background, a growing body of literature has pointed to the transformations in social policies over the past four decades that have made possible these disruptions in the first place. Contributions to this literature have highlighted that the proximate causes and consequences of the Great Financial Crisis (GFC) have to be put into the context of a growing connectivity between social security on the one hand and financial services and financial markets on the other. What is most important is that scholars have argued that the state-sponsored access to financial products has become either a substitute for or a new means of traditional social policy schemes, resulting in what has been called the 'financialization of everyday life' (Hay, 2013; Krippner, 2011; Langley, 2008; Martin, 2002).

This article studies the personal credit dimension of this process. It delineates the relationship between social policy and financial market integration with regard to household borrowing and traces its pervasiveness by drawing attention to the paradigmatically unlikely case of credit-based social policy: Germany. Comparative research on the intersection of finance and welfare has concordantly ascribed a marginal role to loans in German social policy. Rather, a strong tradition of savings promotion and a relatively generous benefit provision in pensions, healthcare and education have been emphasized to underscore that a credit-based 'financialization of everyday life' has not seen a fertile ground in Germany (Garon, 2012; Gerba and Schelkle, 2013; Logemann, 2012b; Prasad, 2012; Roubini, 2011). Indeed, at first sight, there is no reason to dispute this common assessment. While countries as diverse as the United Kingdom, Denmark, Spain, Ireland and, of course, the United States experienced massive credit expansions, mostly in mortgages over the 2000s, bank loans to households in Germany declined in volume from more than 73 percent of gross domestic product (GDP) in 2000 to below 59 percent in $2012 .^{1}$
If one accepts, however, the premise that mainly other factors have caused this deviancy, which can be located in the financial system and the housing market (Kohl, 2015; Mertens, 2017), it seems legitimate to ask if credit-related transformations in German social policy have occurred underneath aggregate debt developments. In fact, welfare state research has tirelessly informed about the expansion of welfare markets, privatization and liberalization in the typical Bismarckian welfare state (Leisering, 2012; Palier, 2010; Seeleib-Kaiser, 2016; Streeck, 2009), motivating a critical reevaluation of the stable images scholarship tends to reproduce in discussing the nexus of social policy and credit in Germany. Furthermore, finance has certainly increased its relevance for social policy-making when pension privatization swept across Europe after the mid-1980s (Naczyk and Palier, 2014), and it seems useful to investigate if the debt-relevant path dependencies presumed on the grounds of historical research really hold.

Following these premises, this article argues that credit in Germany has gradually gained importance for social security over the past four decades due to three parallel developments. First, public promotion of personal savings schemes - the crucial pillar of German savings orientation - has eroded incrementally and has been redirected to policy goals complementary to real estate borrowing. Second, social provision in credit-relevant areas has seen a considerable degree of restructuring and rescaling, increasing the likelihood of compensatory borrowing on the part of private households. Third, quasi-public financial institutions have expanded into this welfare gap by successively targeting loan programmes with social policy content to households since the early 1990s.

Subsequently, the logic of credit-based social policy and financialization has become firmly placed within the German social model, without, however, feeding into a credit boom or triggering large-scale borrowing. Among the reasons for lasting differences to other more credit-relying countries are the sort of social policy instruments used, as well as the degree of financial integration in specific policy fields. Healthcare, for example, despite its fundamental reorganization, has as yet been sheltered from loan interference in Germany, while it has been 
a crucial lever for compensatory credit use in other welfare states. At the same time, the drivers and organizational translation of credit-based social policy have shown a remarkable similarity with Angloliberal economies. As fiscal austerity has come to dominate public policy debates, quasi-public financial institutions have taken over tasks of advancing social policy goals, such as increasing homeownership for low-income households and facilitating higher education access through loans. Against this background, the role of finance in welfare state research must receive greater attention, particularly if the latter wants to investigate common paths and divergent outcomes in the distribution of private and collective risks (Seeleib-Kaiser, 2013). This is even more true for research within the varieties of capitalism framework, which has been debated not only for omitting substantial issues around finance or housing that are at the heart of political economies (e.g. Schwartz and Seabrooke, 2008) but also for its bias towards nationally contained path dependencies (e.g. Bohle and Greskovits, 2009).

In order to substantiate these claims, the article proceeds as follows. It, first, introduces the relevant concepts and theoretical frames, hypothesizing the crucial mechanisms in the rise of credit-based social policy. On this basis, the sections 'The fiscal constitution of saving and its decline in Germany' and 'Borrowing for social security: the credit-welfare nexus in three policy areas' investigate these mechanisms for the German case. While the third section delves into savings promotion, its historical importance and its unnoticed decline, the fourth section revisits the three social policy areas commonly identified as pivotal to credit use: old-age provision, education and healthcare. The material used to trace the developments in the constitution of saving and borrowing through social policy is mainly taken from the budgetary and subsidy reports of the German federal government, as well as from business reports of the large state-owned promotional banks, Kreditanstalt für Wiederaufbau (KfW) and Deutsche Ausgleichsbank (DtA). Publicly available statistical and newspaper sources are used for additional verification of the underlying processes. Finally, the article discusses the dominant view on German social policy and credit, embedding the results in a larger reflection on welfare state research under the conditions of austerity and financialization.

\section{Credit-based social policy: what it is and why it matters}

With the term credit-based social policy, I intend to specify a trending feature of what has been called asset-based welfare. In general, asset-based welfare denotes a policy paradigm that emphasizes the public promotion of private assets as a means of social security. It encompasses the notion that the ownership of shares and property, and even investment in higher education, equips individuals and households with their own buffers handling volatility over the life cycle, particularly during illness, unemployment and retirement. The task of public policy is, thus, to incentivize economic behaviour that facilitates ownership and investment which are, in turn, preventing social hardship through their private insurance character (Prabhakar, 2009; Sherraden, 2005). In all this, it is unclear whether asset-based welfare is supposed to complement or to gradually substitute the traditional provision of income streams such as pensions and unemployment benefits. Related accounts that emphasize the involved processes of privatization and concomitant risk shifts imply the latter (Hacker, 2008).

It seems clear, however, that different welfare states have incorporated elements of asset-based welfare to different degrees, not at least varying to the extent in which public policies promote savings or the debt financing of assets. Germany, as we will see in more detail, has a long history of promoting savings in order to make households more resilient (and a source of capital for the financial-industrial complex). Nonetheless, asset-based welfare has largely been understood as the social policy corollary to the Anglo-liberal growth model, which rested on appreciating property (and stock market) prices and credit-financed consumption in the context of fiscal restraint (Crouch, 2009; Hay, 2011, 2013; Montgomerie, 2013). Public policies prominently targeted credit access and loan conditions for households, for instance, through financial regulation, monetary policy and taxation. In this regard, the well-known 'home mortgage interest deduction' in 
the United States and the 'mortgage interest relief at source' in the United Kingdom have been key policies in advancing homeownership through the tax support of credit financing. Both countries have been said to promulgate 'ownership societies', and it is worth looking at this in order to flesh out what credit-based social policy is about.

Crucially, contemporary welfare state research has highlighted the role of homeownership as a substitute for collectively provided pension benefits. This is because residential property may serve as old-age provision through rent savings, through its rising value that can be realized via specific financial vehicles and through the possibility of tax savings in contrast to other pension benefits (Ronald, 2008: 102). Just as this trade-off is more prevalent in individualistic societies (Castles, 1998), the 'ownership society' is said to be historically engrained in institutions and discourse in Anglo-America. One may think of G.W. Bush's statement that '[t]here's nothing better than providing the incentive to say "this is my asset base, I own it, I will live on it in retirement"' (cited in Langley, 2008: 66; see also Howard, 1997; Ott, 2011). However, the nexus between homeownership and social security has arguably grown tighter since the 1980 s, exacerbated by both financial deregulation and economic and political pressure on the welfare state. As Schwartz (2012) summarizes,

faced with stagnant wages and a falling real value of pensions, health insurance coverage, and other buffers against risk, households increasingly used credit and in particular housing-based credit as a substitute buffer. As welfare state opponents succeeded in shifting risk off the fiscal institutions and onto individuals, housing moved to the forefront of individual strategies for attaining economic security. Home equity became a source of current and future consumption, emergency cash, and disguised retirement savings. (p. 48)

The social (and housing) policies facilitating this trajectory can be clearly traced from Reagan via Clinton to G.W. Bush in the United States and from Thatcher to Blair in the United Kingdom, often reflecting both long-standing conservative and progressive stances on how welfare and finance may interact in a productive or cohesive way (Krippner, 2011; Morgan,
2009; Pierson, 1994; Prasad, 2012; Rajan, 2010; Ronald, 2008). The credit dimension, one should note, was vital to these as to homeownership, in general. ${ }^{2}$ Single episodes of housing privatization, for instance, went along with subsidized or public loans. In the United States, the debt component of asset-based welfare became particularly visible through the organizational backbone of the paradigm, the government-sponsored enterprises (GSEs). What is important is that GSEs, such as Fannie Mae (FNMA), Freddie Mac (FHLMC) and Ginnie Mae (GNMA), were able to lower the cost of mortgages by extending guarantees and building a secondary market for mortgage-backed securities (Fligstein and Goldstein, 2012). Thereby, they could promote homeownership via the lending channel without burdening the public purse.

The explicit mechanisms of this context have found more attention in the analyses of the financial crisis than in social policy research, but have stimulated scholarship to think in more general terms about the relation between finance and welfare (Schelkle, 2012). In a magisterial study on the political origins of the American welfare state, Prasad (2012) proceeds to identify a more general 'credit/ welfare state trade-off' and maintains that households' credit demand is relatively higher where provision of public services is lower. Differences in debt levels between different countries therefore stem from the compensatory character of credit that is not solely visible in housing relations but also valid in general terms. As the American welfare state exemplifies, credit may cushion social risks such as unemployment and illness, serving as a 'debt safety-net' (Montgomerie, 2013; Trumbull, 2012). Additionally, access to credit may compensate for the lack of life cycle-specific public benefits, such as child allowances, and may serve as a lever for social mobility and security, as in the case of education and homeownership (Logemann, 2012a: 203).

Against this background, three sorts of debts are commonly attributed to social policy areas: housing (mortgages), educational (student loans) and medical (credit card). Given the space dedicated to housing above, there should be some clarifications made with regard to the two latter areas. Education, that is primarily higher education, belongs to the 
credit-based social policy perspective as its financing via loans is usually understood as an investment which individuals undertake in order to obtain greater earnings over the life cycle. Student loans in the United States, in fact, have outgrown any other non-secured type of debt and have reached $\$ 1$ trillion in the aftermath of the financial crisis (Federal Reserve Bank of New York, 2013). This type of debt has a fairly long history of public policy facilitation, reaching back to state-backed and subsidized student loans in the 1960s and 1970s and to the subsequent founding of another GSE, the Student Loan Marketing Association, or Sallie Mae (Mettler, 2011). Rising from attempts to extend university opportunities, student finance policy led to a highly commercialized credit market, with a striving market for asset-backed securities based on student loans. The growth of student loans, however, was not a story of institutional innovation alone but rather conditioned by a gradual reduction in public support for higher education - visible in lower per capita spending, as well as in the shift from grants to loans - and a corresponding massive increase in tuition fees (Quinterno, 2012; Williams, 2006).

Healthcare, finally, is not a component of the shift towards credit-based social policy and is harder to identify as a driver of debt. It has until recently, nonetheless, been seen as a vital part in this shift, which justifies its consideration. Its core premise is that under the condition of employer-sponsored healthcare provision, the cost of treatment for many households is too high to be paid out of current income, inducing the use of credit and particularly high-limit credit cards. As there is no statistical mirroring of 'medical debt', evidence comes mainly from bankruptcy evaluations, revealing lower and middleincome groups as the most vulnerable to this form of indebtedness (Jacoby, 2003; Sullivan et al., 2000; Zeldin and Rukaniva, 2007). What distinguishes credit use in this area from housing/old-age provision and education is that social policy does not appear as a direct promoter of loans for healthcare. It rather leaves a welfare gap for a large share of the population, giving credit for medical treatment a pure compensatory character. Although the Affordable Care Act under Obama has presumably eased budgetary pressures on sick individuals, Prasad's (2012) assessment does currently prevail:

In short, there is reason to think that private consumer spending on healthcare - which constitutes the main difference between American and European expenditure patterns - results from an underdeveloped public system of health provision. The American consumer is not maxing out on luxuries but is stretched thin because of healthcare costs. (p. 237)

To summarize, credit-based social policy entails the use of loans as (1) a means of social policy, for instance, through public loan programmes and repayment subsidies, and (2) a substitute for social policy, as is the case when households make use of commercial credit offers in order to obtain social services. ${ }^{4}$ Evidently, the second dimension is much harder to trace empirically since household finances entail complex systems of earmarking, resource shifting and budgeting (Gonzalez, 2015). Nonetheless, it is possible and necessary to validate both dimensions on the macro-level for two reasons. First, financial institutions may follow and legitimize business strategies in the credit market which are directly responding to welfare gaps emerging through retrenchment. Second, as credit markets are politically constituted they become entangled with the two concerns of social policy, redistribution and insurance, independently of household behaviour.

Finally, one may ask to what extent it matters, in general, as well as for Europe and Germany, in particular. The GFC and the following social challenges have evidently revealed the risks that are associated with asset-based welfare and its credit-reliant type, in particular. Two observations stand out. First, the viability of the credit-welfare nexus rests on a whole set of assumptions about both household behaviour and macroeconomic development which are unlikely to prevail, underestimating new volatilities associated with the assets agenda (Erturk et al., 2007; Finlayson, 2009). What is most important is that its success depends on conditions that social policy itself is not able to guarantee, such as rising asset prices in an environment of low inflation and low interest rates (Hay, 2013: 29). Second, the risks households have to bear in a debt-financed assetbased system of social security are unequally 
distributed, leaving some households with a greater likelihood of their investments not paying off and possibly pushing them into bankruptcy. The remaining safety net, then, is a market-based insolvency regime (Carruthers and Ariovich, 2010; Heuer, 2014).

Until now, there is little cross-national research on how the trends outlined in this section have spread across the Organization for Economic Cooperation and Development (OECD), but there are several indications that they have not been restricted to the Anglophone economies (Andrews et al., 2011; Gerba and Schelkle, 2013; Peters, 2012; Vossensteyn et al., 2013). Nonetheless, Germany remains the paradigmatic counter case in the literature mainly due to two representations: first, scholars have highlighted its system of savings promotion with a dense network of savings banks and a wide array of public policy measures. Most fundamentally, the latter entail the promotion of equity capital to substantiate high down payments for homeownership, giving asset-based welfare a strict savings orientation (Garon, 2012; Logemann, 2012b). Second, old-age provision, healthcare and education are essentially public tasks. A correspondingly high level of public provision and welfare state generosity are said to diminish credit demand as there is less need to compensate for welfare gaps (Prasad, 2012; Roubini, 2011). Both features are frequently associated with reinforcing a comparatively low homeownership rate in Germany that has meandered around 45 percent over the past decade and, thereby, has kept in check housing-cumdebt bubbles (Kohl, 2014; Schwartz and Seabrooke, 2008). Interestingly, these arguments have also resonated with German consumer associations that have repeatedly explained a comparatively low prevalence of indebted households with robust welfare spending and the promotion of savings (Arbeitsgemeinschaft der Verbraucherverbände e.V. and Deutsches Rotes Kreuz, 1994; Verbraucherzentrale Bundesverband et al., 2005).

The following empirical sections put these representations to a test. I suggest that the assumed marginal role of credit in German social policy tends to underestimate the growing importance of the creditwelfare nexus and has unduly stressed the stability of German welfare state arrangements. Furthermore, the sections reveal striking parallels to the mechanisms outlined above, even though the developments in Germany are of a more recent date, happening on a lower scale. I begin by revisiting the first representation of the German savings regime, its system of savings promotion.

\section{The fiscal constitution of saving and its decline in Germany}

Classifying vital elements of German social policy as savings-based rather than credit-based has its fundament in the immediate postwar period. Currency reform and housing reconstruction fuelled government action to bolster private savings activity. A sequence of laws between 1948 and 1961 allowed tax exemptions on capital insurances, as well as building society contributions and offered premiums on both current account and building society savings. Exemplifying the corporatist character of the German welfare state, the promotion of savings and equity also found its way into collective bargaining contracts, incentivizing employers and employees to increase savings through tax breaks ('vermögenswirksame Leistungen' or capital-forming benefits). After a period of initial institutionalization, distributional goals became a greater focus of savings promotion that started to emphasize capital formation for lower and middle-income groups. At this time, public policy reflected and reinforced the notion of 'saving first, buy later' in both consumption and asset creation (Börsch-Supan, 1994).

The promotion of savings also entailed a strong growth regime relevance as it was in part motivated by policy-makers' urge to restrain consumption (German Ministry of Finance (BMF), 1963: 70). For this reason, they abolished a long-standing credit-enhancing tax break - the 1920's income tax law on interest deduction - in 1973 (German Parliament 7/419: 46). ${ }^{5}$ As a result and in interplay with generally improving socio-economic conditions, private savings soared in the postwar period, summing up to 15.1 percent of disposable income in 1975. At this time, savings promotion did not rely solely on a range of public policy instruments but also on a growing implementation in employment relations: in 1980,94 percent of all 


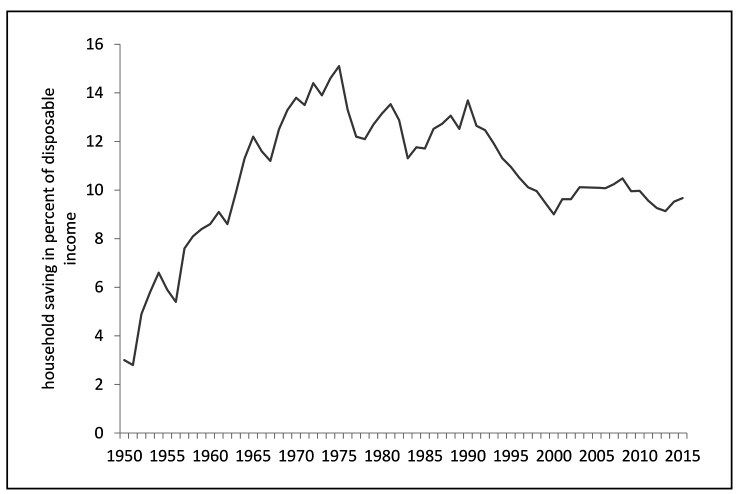

Figure I. Crumbling foundations: household savings in the long term, 1950-2015.

Source: German Federal Statistical Office.

collective bargaining contracts contained a passage on capital-forming benefits (Federal Government, 1965-2014: 8th Subsidy Report: 42). Additionally, commercial offers for building society contracts, insurances and bank accounts entailed the praise of public subsidies. In other words, savings promotion had become engrained in the social and economic order of the young Federal Republic. ${ }^{6}$

In 1975, the savings regime had, however, already begun to crumble. Savings rates successively declined from an all-time high of 11.3 percent in the early 1980s and then to 9.0 percent in 2000. In 2015, it was 9.7 percent again (Figure 1). ${ }^{7}$ While several factors may account for this decline, it strikingly corresponds to what happened with public savings promotion. Increasingly facing criticism to be outdated and less progressive than assumed, the savings instruments in the government's policy toolbox became the aim of policy-makers' efforts for fiscal consolidation. On one hand, this materialized in non-adjustments to eligibility, particularly with regard to income, decreasing the number of potential benefiters (15th Subsidy Report: 39). On the other hand, budget reform legislation reduced the premiums and allowances for current account and building society savings (BMF, 1977: 54). Savings premiums remained the largest financial aid for private households in the public budget but not for long. In 1981, the German parliament abolished the Savings Premium Law and, additionally, curbed the level of the remaining support schemes (BMF, 1981: 54).
The subsequent conservative government under chancellor Kohl continued with the retrenchment of savings promotion in the name of budget consolidation (BMF, 1984: 137-8) and removed the remaining fiscal support for current account and insurance savings completely (BMF, 1989: 1123 ). Only Reunification put a hold on further cuts. Special premiums and extended eligibility were supposed to support asset formation in the New Länder, helping to make the former German Democratic Republic (GDR) part of a capitalistic welfare state (BMF, 1991). Even though this fed back to the general savings promotion legislation (16th Subsidy Report: 148) and further reductions in capital-forming benefits were successfully objected to by the building societies, the German public policy of savings promotion at the end of the 1990s was only a shadow of its postwar significance. Despite the fact that the pension privatization of 2001 made use of the savings promotion tradition, the maximum premia for forming equity capital in building societies after a 2004 reform accrued to $€ 45$ annually, thereby being more of a symbolic instrument (20th Subsidy Report: 41-2).

Further pension and tax reforms in 2008 and 2009 have continued to restrict savings promotion (22nd Subsidy Report: 32), which only admits the conclusion that the material foundations of the German savings regime, connecting economic and social objectives, have been seriously dismantled. The concomitant erosion of collective bargaining in Germany (Streeck, 2009) has additionally undermined the anchoring of savings promotion on the company level. Figures 1 and 2 underscore this assessment. In particular, the decline of savings promotion as a share of subsidies in Figure 2 is striking, with most changes being politically induced and not subject to business cycle volatility. Nominally, federal savings promotion decreased from $€ 5$ billion in 1975 to $€ 807$ million in 2014 , now leaving the savings preferences of private households more than ever subject to 'market forces'. Nevertheless, these reforms relate closely to the trajectory of pension policies, which is the first focus of the following section on the creditrelevant areas of welfare state reform. 


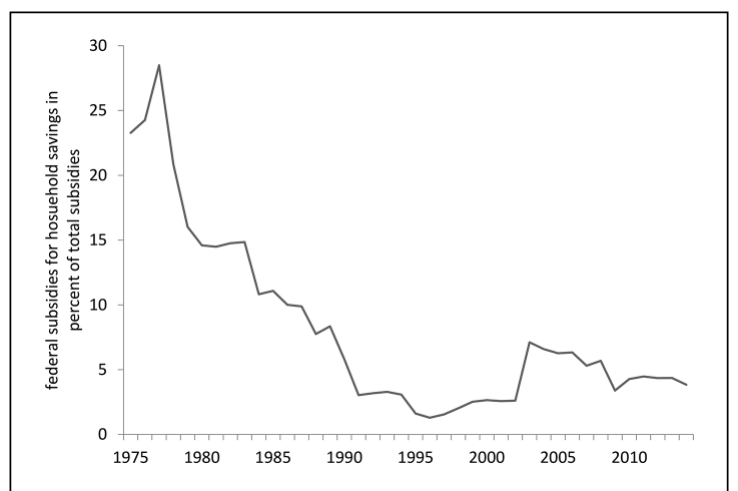

Figure 2. The erosion of public savings promotion, |975-20|4.

Source: German Federal Subsidy Reports; own calculations.

\section{Borrowing for social security: the credit-welfare nexus in three policy areas}

\section{What sort of safe haven? Old-age provision and homeownership}

In the light of scholarly discussions around the relation between pensions and homeownership, it is worth tracing that connection in the German welfare state, particularly after Reunification. There is little doubt that contemporary public debates in Germany have fully reflected the pressures on households to become active in providing for their retirement, and that obtaining homeownership is a pivotal means to this end. A simple content analysis of one of Germany's largest newspapers (Frankfurter Allgemeine Zeitung) reveals that 'old-age provision' and 'homeownership' have seen a significant increase in being discussed in relation to each other over time (Table 1). This largely reflects changes in social policy and, most importantly, the consecutive pension reforms of 2001 and 2008.

In the postwar era, savings in insurances were the primary locus of politically subsidizing the private pillar of old-age provision (BMF, 1967: 199), while the public promotion of homeownership was mainly discussed in the context of family policy and reconstruction - especially under the lead of Christian Democrats (Schulz, 1988). Owner-occupied housing, nonetheless, was mostly secondary compared to rental
Table I. Joint discussion of 'old-age provision' and 'homeownership', F.A.Z., 1970-2009.

Period Number of articles

$\begin{array}{rr}1970-1979 & 1 \\ 1980-1989 & 11 \\ 1990-1999 & 46 \\ 2000-2009 & 273\end{array}$

Source: Frankfurter Allgemeine Archiv BiblioNet. Original search terms are 'Altersvorsorge' and 'Wohneigentum' (terminology robustness checked with 'Rente' and 'Eigenheim').

and social housing in social policy considerations. This assessment looms large in contemporary reflections on the issue of credit-based social policy, fitting nicely into the additional features of low rates of homeownership and low degrees of pension capitalization (Schwartz and Seabrooke, 2008). Nonetheless, as observers of the German welfare state have noticed, changes in both fields have accumulated; in a way, I would add, that has strengthened the link between housing (credit) and pensions (welfare).

Naturally, pension reform is at the heart of this trend. First, the average level of pension generosity has gradually decreased since the mid-1980s due to a number of adjustments such as indexation, new calculation formulas and deliberate non-increases. Figure 3 illustrates the impact of these adjustments on replacement rates for both single and single-earner family households. There is little doubt that the political goal to stabilize the pension system through these reforms was strongly linked to the impetus of fiscal consolidation (Zohlnhöfer, 2009). It is important to note that these cuts do not necessarily affect the credit/welfare state trade-off by putting pressures on current pension receivers but rather by exerting pressures on future generations of pensioners, who are increasingly convinced that they should not rely on public pension schemes. This becomes particularly evident when individual housing preferences are taken into account (Helbrecht and Geilenkeuser, 2010): while older people consider their home very infrequently as a private pension scheme, younger cohorts of Germans increasingly understand the purchase of residential property as an asset-based pension strategy that may presuppose debt financing and is forced upon them by welfare state restructuring. 




Figure 3. Dismantling pensions: average pension replacement rates, 1975-2011.

Source: Scruggs et al. (2014) 'Comparative Welfare Entitlements Data Set'; own illustration.

Replacement rates are calculated for a fictive average production worker in the manufacturing sector, either without dependents ('Single') or with two children and a dependent spouse ('Family'); the reference wage is the 'average production worker wage' and includes all cash transfers from general government.

The increase of the German ownership ratio between 1990 and 2011 from 37.7 to 45.6 speaks to these results in a very straightforward way, only underscored by the fact that public expenditure on housing declined in the same period from 1.47 percent of total expenditure to 0.68 percent. $^{8}$

Crucially, the details of pension reform have also reflected this nexus. The initial Riester-Rente of 2001 explicitly entailed a subsidized scheme in which private savings could be used for the purchase of a home, though within strict limits (BMF, 2002: 148). However, since several banking and homeownership associations saw housing being discriminated against as a pension-relevant asset, a further reform process set in which resulted in a more liberal scheme. ${ }^{9}$ In brief, this Home Owner Pension Act (Eigenheimrentengesetz) entailed that pension savers were allowed to use their subsidized savings for the purchase, construction or debt repayment of owner-occupied housing. What is most important is that mortgage repayments themselves became eligible for subsidies (BMF, 2009: 349). Social policy reforms, thus, legislatively anchored the nexus between debt-financed homeownership and private retirement provision, acknowledging the credit-asset link in old-age provision (CDU et al., 2009).
The finding for a turn to credit-based social policy in this field receives even starker support when we take into account the role of public loan programmes and the rise of an actor usually unknown in social policy scholarship: promotional or development banks. The German KfW got involved in this process by implementing a homeownership programme in 1996, at the same time when the government implemented the first-home buyer grant. Before that the KfW had rarely set up programmes for private households but rather for industry and municipalities. Initially small and targeted at young families, the programme quickly grew to a fully fledged loan scheme to support homeownership in the face of welfare state reform. ${ }^{10}$ The state-owned bank legitimized the programme by explaining,

In the light of demographic pressures, private oldage provision becomes increasingly important. Homeownership takes on a central role here. KfW has extended its programme to promote homeownership for young families to an encompassing programme to promote homeownership in 2000. Everyone who purchases or newly constructs their own residential property, may receive a low-interest promotional loan from the KfW. (KfW, annual report, 2000: 34; own translation)

At the very same point in time, the KfW began to set up a programme to foster the securitization of mortgages. The platform Provide-Residential Mortgage Securitization (PROVIDE) should lift profitability issues of lenders and support the mortgage market. Although low in scale, synthetic and of short living, it underscored the KfW's claim to become the prime promoter of homeownership in fiscally hard times. In fact, it was at the heart of shifting the public ownership promotion from grants and savings to loans, particularly if you consider the erosion of the savings promotion for building societies depicted above. As Figure 4 illustrates, the KfW quickly expanded its loan volume after the late 1990 s, celebrating the support of 820,000 first-home buyers on the tenth anniversary of the programme in 2006 (KfW, 2006: 48). Nonetheless, the overall impact on borrowing remains somewhat diffuse as the loans are admitted through private bank activity (on-lending principle), and one may argue that the future of this programme 


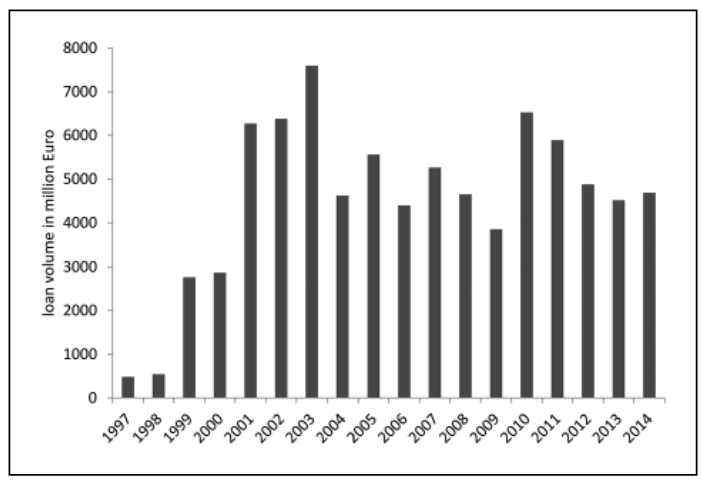

Figure 4. The $\mathrm{KfW}$ as a new provider: annual volume of credit approvals from the 'homeownership programme', 1997-20I4.

Source: KfW Annual Business Reports, 1998-2015; own calculations.

is insecure to the extent that newer programmes for homeowners contain a greater focus on environmental-friendly home improvements (as mirrored in the post-2010 data in Figure 4).

\section{Public goods and credit: financing education}

With pension reforms converting homeownership into an asset and with the help of the KfW, fostering a shift from grants to loans, the analogy to the AngloAmerican trajectory becomes evident, and it raises the question of whether we can identify a similar trend in the field of higher education. Interestingly, a 1973 study of savings promotion systems across the OECD classified Germany as exceptional in so far as 'the financing of training and university education is not seen as a task for private provision, but represents a public task in its own right' (Albach et al., 1973: 154). Only a few years earlier, the social-liberal government had introduced a legal claim to state subsidies for educational reasons. Certainly, there was no sign of loan programmes for educational means. As the reader may expect, the financing balance between the state and households did not remain stable over the decades. Particularly within higher education financing, the loan principle gained wider relevance.

Again, the budgetary reform of 1975 marked a crucial starting point for the rise of credit-based social policy. What is most important is that it added to the public subsidy scheme for students (BAföG) an interest-free loan component (BMF, 1975, 1978). Similar to the reform of savings promotion, policymakers additionally tried to contain the costs of $B A f \ddot{o} G$ through the non-adjustment of eligibility criteria such as income limits. After 1982, the Christian Democrat-led government cut the levels of financial support and fully transformed it into an interest-free loan-based scheme for the sake of fiscal consolidation (BMF, 1984: 61). While this feature and concomitant levels were changed back and forth over the following decades, in 1996 the same government transferred parts of the educational subsidy system to another promotional bank, the Deutsche Ausgleichsbank (DtA), which later was vertically integrated in the KfW. The DtA took care of new interest-based loan schemes in the $B A f \ddot{o} G$-system, equipped with state guarantees (BMF, 1996: 30, 1998: 30). Because of these shifts, federal financial support for students decreased under conservativeliberal rule from 1.05 percent of total spending in 1982 to 0.37 percent in $1998 . .^{11}$

While the succeeding government, under social democratic leadership (1998-2005), halted this development by slightly increasing funding rates and limiting the possible debt burden to $€ 10,000$ (BMF, 2002: 44, 2003: 44), other institutional reforms enforced the credit component of higher education financing. For instance, in 2001 the DtA and the federal government originated an education loan programme for 'extraordinary expenses', such as stays abroad (DtA, 2003: 24), which had approved $€ 800$ million in loans until 2011 (BMBF, 2013). What is most important, however, is that a longstanding political conflict about the introduction of tuition fees had reached its high point in 2005. A constitutional court ruling resulted in the widespread diffusion of average fees of $€ 1,000$ per year among German universities in the subsequent years, doubtlessly increasing financial pressures on households and prospective students. The remedy proposed by the Christian Democrats, almost obvious, was a student loan programme intended to help households compensating for these tuition fees (Krause, 2008).

After another change in government in 2005, the KfWreceived the order to implement a student loan 
programme, thereby building a market for a financial product that had previously been seen as too risky from the side of retail banks. Selling the introduction to the public as a 'highlight of education financing' (KfW, 2006: 5), the KfW found legitimization again in the emerging welfare gap (KfW, 2004: 55, 2005: 11, 2006: 16, 2011: 35). In its corresponding strategy to prevent students from overindebtedness, the promotional bank asked the borrowers for proof of certificates during the loan period, underlining the hierarchical and disciplinary nature of the creditor-debtor relationship (cf. Soederberg, 2014). As soon as the KfW (2011) had approved 100,000 student loans, it portrayed the programme as an 'irrevocable instrument for the financing of higher education' (p. 49). Figure 5 shows the remarkable rise of quasi-public educational loans in Germany between 1998 and 2014, not accounting for the activities of commercial banks in this segment, which had followed the lead of the KfW after 2005 and made up around 50 percent of the market (KfW, 2008: 62). Since the German Länder abolished tuition fees again in 2014 , it remains to be seen if the loan volume continues to rise. Without doubt, and despite the low levels of overall debt, credit has become a means of social policy in the field of education, and given the cost shift also a substitute for former public provision.

\section{Healthcare on credit?}

Contrary to the fields of pensions and education, healthcare in Germany seems much less associated with the borrowing behaviour of German households. As medical debt is difficult to measure, one of the few sources to assess its prevalence is the European household survey on living conditions (EU-SILC). According to a one-time survey module from 2008, only 1.1 percent of households had taken out a loan to finance medical treatment. ${ }^{12}$ These treatments, however, may also involve cosmetic operations to which commercial banks commonly refer when they offer 'health loans'. As this hinders general inferences about the trade-off character of credit in healthcare, the only part of the macro-link that one can currently reconstruct in a plausible way is the gradual restructuring of healthcare in Germany.

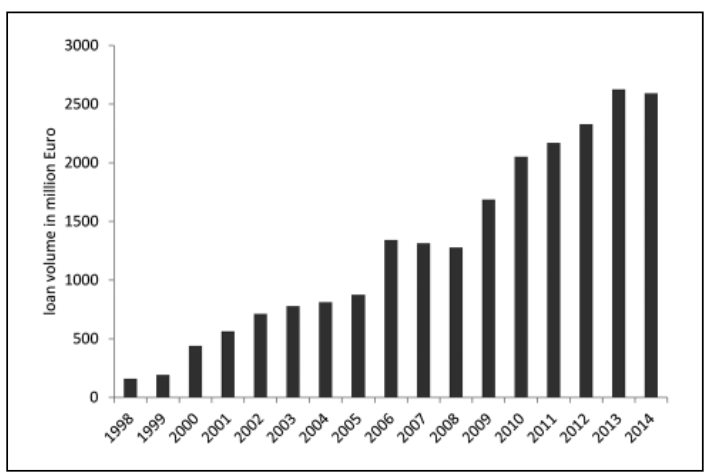

Figure 5. The $\mathrm{KfW}$ as a market maker: annual volume of credit approvals for educational means.

Source: KfW Annual Business Reports, 1998-2015; own calculations.

Scholars of the German healthcare system usually agree on the fact that it has seen several transformations since the early 1980 s which are mostly associated with processes of rescaling, privatization and marketization (Hassenteufel and Klenk, 2013). While privatization processes, for instance in the hospital sector, might only increase budgetary pressures on households with a significant time lag, other reforms have successfully shifted costs from companies and public administration on to households in the short term (Gerlinger and Schmucker, 2009). What is most important is that legislation in the mid1990s introduced several benefit reductions and raised individual contributions to specific services. In the early- and mid-2000s, the social democraticled government followed this trend to some extent when it 'modernized' the public health insurance scheme, finally leading to the abolition of parity between employers and employees in healthcare finance to the disadvantage of the latter. Moreover, and independent of the insurance contributions, the public budgets reduced their share of healthcare financing between 1995 and 2014 from 10.7 percent to 4.5 percent; households, however, accounted for 13.1 percent of healthcare expenditure in 2014 , as compared to 10.3 percent in $1995 .{ }^{13}$

These tendencies are relevant insofar that consumer lenders see some market potential in them. The association of consumer banks, for instance, has indicated that they prepare for growing credit demand just 
as statutory health insurers begin to cover fewer services. ${ }^{14}$ Such tie-ins should sharpen academic attention towards the possible substitute effects of credit use in social policy, but as German healthcare still appears to be relatively strong and collectively funded in international comparisons, ${ }^{15}$ it drastically differs from the trends seen in other social policy areas.

\section{Conclusion}

It was as late as 1999 that the German legal apparatus began to offer personal insolvency proceedings for over-indebted consumers and homeowners. In the second half of the 2000s, each year around 100,000 individuals took advantage of the new possibility to declare personal bankruptcy. This dramatic policy change resonates well with this article's finding that the logic of credit-based social policy is not alien to the German welfare state. While scholarship on the credit-welfare nexus conceptualizes Germany as the paradigmatic and stable case for strong savings promotion, high public provision of social services and credit marginality in social policy, this article delineated a gradual, transformative reform process that casts doubts on this representation. First, the fundamental pillar of the savings regime - public policy promoting savings - has crumbled over the years, thereby eroding crucial material incentives for capital forming. Second, in all mentioned policy areas, fiscal pressures have fuelled reform processes that subsequently increased households' financial and structural responsibility for social security. Third, and last, policy-makers and promotional banks have used loan principles and programmes as policy options in order to cushion retrenchment and restructuring in old-age provision and education. As a result, credit has become both a means of and a substitute for traditional social policies.

Evidently, there are caveats in this diagnosis. The scope of the depicted programmes is still significantly smaller than what researchers have revealed about Anglo-America's credit reliance in social security, particularly with regard to healthcare. Therefore, one should be careful about inferences for aggregate household debt levels and other macroeconomic indicators, such as the savings ratio. Rather, the existence of striking parallels should catch the attention of scholars who may link these with debates about diffusion processes and interdependencies between Western welfare states under pressure. The role of state-owned or governmentsponsored promotional banks that incorporate social policy goals and pursue them via the construction of credit markets is a case in point. Their specific position in policy-making allows for some sort of offbalance sheet social policy: the democratically legitimated aim to improve social participation may be followed without using public spending per se, but by mediation through quasi-public financial institutions.

While this is different from privatization, it is linked to processes of marketization. This raises the almost obligatory question about whether the rise of credit-based social policy marks a turn away from the German social model and to what extent one can convincingly talk of a real redirection in social policies. The empirical evaluation presented here suggests three exhibits in favour of a qualitative shift, leaving aside the problem of setting a benchmark or quantitative threshold: first, reform content in pension and education policies is explicitly linked to the access to financial services, in a way that is very different from the postwar state-funded loans in the housing market; second, the timing and meshing of social policy reform, retrenchment and financial sector involvement in the 1990s and 2000s is striking and underlines the notion of a new dimension in social policy-making; third and last, the framing of semi-public and private loan programmes as social policies has created a discursive foundation for the entanglement of welfare and finance that qualifies as novel.

Even though the trajectory shown displays cumulative reform processes that become transformative through layering and drift, as institutional analysis suggests (Streeck and Thelen, 2005); the tendencies are often issue-specific and contingent, cutting across the traditional characteristics of the conservative-corporatist welfare state. There is no doubt, however, that the regularly noted savings dimension of the German regime and its asset-based welfare policies is severely under pressure. This is not solely because of the dismantling of savings-oriented policies but also because of savings banks abandoning 
their role as moral institutions (Belvederesi-Kochs, 2012). Further scepticism is apt due to the current low-interest rate environment, which is likely to form a new incentive regime around debt-financed assets.

The distributional consequences of these changes remain largely unexplored to date, but will emerge as a promising and important focal point of research around the credit issues presented here. The actual risks associated with debt-financed social security are probably unevenly distributed, as are the capabilities to deal with them (Erturk et al., 2007). Recent evidence from US household surveys reveals that wealthier households are the ones that embrace and profit from the sort of financialized social security prevalent in the American welfare state (Fligstein and Goldstein, 2015). Accordingly, the relatively recent endeavour of the European Central Bank to produce a European survey on household finances may deliver an analogous dataset from which to explore the distributional issues around credit-based social policy. Given the impression that consumer protection and bankruptcy policies have become more important both as tools and as an unintended consequence of the delineated shifts, such are not simply technical matters, but touching upon the very stability of contemporary welfare states and its societies.

\section{Acknowledgements}

An earlier version of this article was presented at the $23 \mathrm{rd}$ International Conference of Europeanists in Philadelphia in April 2016. I am grateful to the panel participants, Mark Vail, Alexander Reisenbichler and two anonymous reviewers for engaging and valuable feedback.

\section{Funding}

The author(s) received no financial support for the research, authorship and/or publication of this article.

\section{Notes}

1. Organization for Economic Cooperation and Development (OECD) Financial Balance Sheets, non-consolidated; retrieved on 24 November 2014.

2. As most owner-occupied housing must be financed in advance, mortgage debt accounts for 60-90 percent of all household liabilities in OECD countries, following data from the European Credit Research Institute (2011).

3. However, Hills (2011) sees a general increase in demand for healthcare services in ageing societies, challenging public supply and budgeting across the OECD.

4. Arguably, one could extent the means-category by a debtor-friendly bankruptcy regime and the role indebted households play in social policy-making. See for this Niemi et al. (2009) and below.

5. The interest deduction for mortgages was again debated and temporarily activated as a policy tool for tackling economic and housing crises in the 1980s and 1990 s, but faced strong objections by the building societies. To be sure, the immediate postwar policies entailed a couple of loan-based housing instruments alongside the interest deduction. However, they neither gained as broad attention as savings instruments nor did they outlive the reconstruction period as explicit social policies.

6. There is an interesting overlap of savings-based and credit-based social policies when considering building societies as a promotion of mutual savings contracts entails both the strengthening of down payments and the possibility to obtain a second-order mortgage. In this sense, the proposed classifications are necessary relative concepts against a wider universe of cases reflected upon above.

7. It is worth noting that the usual reading of this graph is that Germany has a quite consistently high savings ratio. In my reading, however, there is a greater need to reflect the historical fluctuation that comes with it. Recent evidence on the composition of savings also underlines a deeper transformation: while during the expansionary decades savings increased across income groups, contemporary stability of the ratio is predominantly upheld by the top quartile of the income distribution just as the three other quartiles have continued to reduce their savings (Stein, 2009).

8. Analogously to the savings ratio, the ownership ratio is another indicator which is usually discussed as a snapshot in cross-national comparisons ('Germany has a low ownership ratio'). Again, the historical data show a remarkably stable increase over time. Ownership data are found in SOEP (2013), additionally revealing that although Reunification boosted ownership rates in the East through privatization policies, homeownership in West Germany rose by the same eight percentage points, reflecting a more general trend in household behaviour, Housing 
expenditure is calculated from Federal Statistical Office data on the public budget (Fachserie 14; Reihe 3.1).

9. Interview with mortgage/covered bond-banking association $v d p$ on 13 February 2013. The depicted process intensified with the decision of the social democratic-led government in 2004 to abolish the first-home buyer grant that had existed since 1996 and had subsidized homeownership with state funding.

10. I rely here on an internal paper of the KfW (14 May 2013, personal communication,).

11. Federal Statistical Office, Fachserie 14, Reihe 3.1.

12. However, in fact, only Bulgaria, Iceland, Poland and Cyprus had higher ratios. See http://ec.europa.eu/ eurostat/documents/1012329/1012401/2008+ad+hoc + module+data.xls, variable MI056; last accessed on 30 June 2017, own calculations.

13. Federal health reporting, accessible at http://www. gbe-bund.de/.

14. Interview with Bankenfachverband on 15 February 2013.

15. OECD Social Expenditure Database, retrieved 15 February 2014.

\section{References}

Albach, H., Krelle, W., Siebke, J. and Wittmann, W. (1973) Probleme der Sparförderung in der OECD. Berlin: Duncker \& Humblot.

Andrews, D., Sánchez, A.C. and Johansson, A. (2011) Housing Markets and Structural Policies in OECD Countries. Paris: OECD.

Arbeitsgemeinschaft der Verbraucherverbände e.V. and Deutsches Rotes Kreuz (1994) Schuldenreport 1993: Die Verschuldung der privaten Haushalte in Deutschland. Neuwied; Kriftel; Berlin: Luchterhand.

Belvederesi-Kochs, R. (2012) 'Moral or Modern Marketing? Sparkassen and Consumer Credit in West Germany', in J. Logemann (ed.) The Development of Consumer Credit in Global Perspective: Business, Regulation, and Culture, pp. 41-62. New York: Palgrave Macmillan.

BMBF (2013) Bildungskreditprogramm im Überblick. Berlin: Bundesministerium für Bildung und Forschung.

Bohle, D. and Greskovits, B. (2009) "Varieties of Capitalism and Capitalism "Tout Court", European Journal of Sociology 50(3): 355-86.

Börsch-Supan, A. (1994) 'Savings in Germany - Part 1: Incentives', in J.M. Poterba (ed.) Public Policies and Household Savings, pp. 81-104. Chicago, IL: University of Chicago Press.
Carruthers, B.G. and Ariovich, L. (2010) Money and Credit: A Sociological Approach. Cambridge: Polity Press.

Castles, F.G. (1998) 'The Really Big Trade-Off: Home Ownership and the Welfare State in the New World and the Old', Acta Politica 33: 5-19.

CDU, CSU and FDP (2009) Wachstum. Bildung. Zusammenhalt. Koalitionsvertrag zwischen CDU, CSU und FDP. Berlin: CDU, CSU and FDP.

Crouch, C. (2009) 'Privatised Keynesianism: An Unacknowledged Policy Regime', The British Journal of Politics \& International Relations 11: 382-99.

DtA (2003) Geschäftsbericht 2002. Bonn: Deutsche Ausgleichsbank.

Erturk, I., Froud, J., Johal, S., Leaver, A. and Williams, K. (2007) 'The Democratization of Finance? Promises, Outcomes and Conditions', Review of International Political Economy 14(4): 553-75.

European Credit Research Institute (2011) Lending to Households in Europe (1995-2010). Brussels: ECRI.

Federal Government (1965-2014) Bericht der Bundesregierung über die Entwicklung der Finanzhilfen des Bundes und der Steuervergünstigungen (Subsidy Report). Bonn; Berlin: Deutscher Bundestag and BMF.

Federal Reserve Bank of New York (2013) Quarterly Report on Household Debt and Credit Q3. New York: Research and Statistics Group.

Finlayson, A. (2009) 'Financialisation, Financial Literacy and Asset-Based Welfare', The British Journal of Politics \& International Relations 11(3): 400-21.

Fligstein, N. and Goldstein, A. (2012) 'A Long Strange Trip: The State and Mortgage Securitization, 19682010', in K. Knorr Cetina and A. Preda (eds) The Oxford Handbook of the Sociology of Finance, pp. 339-56. Oxford: Oxford University Press.

Fligstein, N. and Goldstein, A. (2015) 'The Emergence of a Finance Culture in American Households, 19892007', Socio-Economic Review 13(3): 575-601.

Garon, S. (2012) Beyond Our Means: Why America Spends While the World Saves. Princeton, NJ; Oxford: Princeton University Press.

Gerba, E. and Schelkle, W. (2013) The Finance-Welfare State Nexus: ACES Cases, 2013.1. Washington, DC: American Consortium on EU Studies.

Gerlinger, T. and Schmucker, R. (2009) 'A Long Farewell to the Bismarck System: Incremental Change in the German Health Insurance System', German Policy Studies 5(1): 3-20. 
German Ministry of Finance (BMF) (1963) Finanzbericht: die volkswirtschaftlichen Grundlagen und die wichtigsten finanzwirtschaftlichen Probleme des Haushaltsplans der BRD für das Rechnungsjahr (Financial Report). Bonn: BMF.

German Ministry of Finance (BMF) (1967) Finanzbericht: die volkswirtschaftlichen Grundlagen und die wichtigsten finanzwirtschaftlichen Probleme des Haushaltsplans der BRD für das Rechnungsjahr (Financial Report). Bonn: BMF.

German Ministry of Finance (BMF) (1975) Finanzbericht: die volkswirtschaftlichen Grundlagen und die wichtigsten finanzwirtschaftlichen Probleme des Haushaltsplans der BRD für das Rechnungsjahr (Financial Report). Bonn: BMF.

German Ministry of Finance (BMF) (1977) Finanzbericht: die volkswirtschaftlichen Grundlagen und die wichtigsten finanzwirtschaftlichen Probleme des Haushaltsplans der BRD für das Rechnungsjahr (Financial Report). Bonn: BMF.

German Ministry of Finance (BMF) (1978) Finanzbericht: die volkswirtschaftlichen Grundlagen und die wichtigsten finanzwirtschaftlichen Probleme des Haushaltsplans der BRD für das Rechnungsjahr (Financial Report). Bonn: BMF.

German Ministry of Finance (BMF) (1981) Finanzbericht: die volkswirtschaftlichen Grundlagen und die wichtigsten finanzwirtschaftlichen Probleme des Haushaltsplans der BRD für das Rechnungsjahr (Financial Report). Bonn: BMF.

German Ministry of Finance (BMF) (1984) Finanzbericht: die volkswirtschaftlichen Grundlagen und die wichtigsten finanzwirtschaftlichen Probleme des Haushaltsplans der BRD für das Rechnungsjahr (Financial Report). Bonn: BMF.

German Ministry of Finance (BMF) (1989) Finanzbericht: die volkswirtschaftlichen Grundlagen und die wichtigsten finanzwirtschaftlichen Probleme des Haushaltsplans der BRD für das Rechnungsjahr (Financial Report). Bonn: BMF.

German Ministry of Finance (BMF) (1991) Finanzbericht: Stand und voraussichtliche Entwicklung der Finanzwirtschaft im gesamtwirtschaftlichen Zusammenhang (Financial Report). Bonn: BMF.

German Ministry of Finance (BMF) (1996) Finanzbericht: Stand und voraussichtliche Entwicklung der Finanzwirtschaft im gesamtwirtschaftlichen Zusammenhang (Financial Report). Bonn: BMF.

German Ministry of Finance (BMF) (1998) Finanzbericht: Stand und voraussichtliche Entwicklung der Finanzwirtschaft im gesamtwirtschaftlichen Zusammenhang (Financial Report). Bonn: BMF.
German Ministry of Finance (BMF) (2002) Finanzbericht: Stand und voraussichtliche Entwicklung der Finanzwirtschaft im gesamtwirtschaftlichen Zusammenhang (Financial Report). Bonn; Berlin: BMF.

German Ministry of Finance (BMF) (2003) Finanzbericht: Stand und voraussichtliche Entwicklung der Finanzwirtschaft im gesamtwirtschaftlichen Zusammenhang (Financial Report). Bonn; Berlin: BMF.

German Ministry of Finance (BMF) (2009) Finanzbericht: Stand und voraussichtliche Entwicklung der Finanzwirtschaft im gesamtwirtschaftlichen Zusammenhang (Financial Report). Bonn; Berlin: BMF.

Gonzalez, F. (2015) 'Where are the Consumers? "Real Households" and the Financialization of Consumption', Cultural Studies 29(5-6): 781-806.

Hacker, J.S. (2008) The Great Risk Shift: The New Economic Insecurity and the Decline of the American Dream. New York: Oxford University Press.

Hassenteufel, P. and Klenk, T. (2013) 'Germany: Mixing Rescaling, Privatization and Managerialism', in E. Pavolini and A.M. Guillén (eds) Health Care Systems in Europe under Austerity: Institutional Reforms and Performance, pp. 126-46. Basingstoke: Palgrave Macmillan.

Hay, C. (2011) 'Pathology without Crisis? The Strange Demise of the Anglo-Liberal Growth Model', Government and Opposition 46(1): 1-31.

Hay, C. (2013) The Failure of Anglo-Liberal Capitalism. Basingstoke: Palgrave Macmillan.

Helbrecht, I. and Geilenkeuser, T. (2010) 'Homeownership in Germany: Retirement Strategies of Households in a Tenant Society', Teorija in Praksa 47(5): 975-93.

Heuer, J.-O. (2014) Rules and Norms of Consumer Insolvency and Debt Relief: A Comparison and Classification of Personal Bankruptcy Systems in 15 Economically Advanced Countries. PhD Dissertation, University of Bremen, Bremen.

Hills, J. (2011) 'The Changing Architecture of the UK Welfare State', Oxford Review of Economic Policy 27(4): 589-607.

Howard, C. (1997) The Hidden Welfare State: Tax Expenditures and Social Policy in the United States. Princeton, NJ: Princeton University Press.

Jacoby, M.B. (2003) 'Generosity versus Accessability: Bankruptcy, Consumer Credit, and Health Care Finance in the US', in J. Niemi-Kiesilainen, I. Ramsay and W.C. Whitford (eds) Consumer Bankruptcy in Global Perspective, pp. 283-300. Oxford: Hart Publishing.

Kohl, S. (2014) Homeowner Nations or Nations of Tenants: How Historical Institutions in Urban Politics, Housing Finance and Construction Set 
Germany, France and the US on Different Housing Paths. PhD Dissertation, University of Cologne, Cologne.

Kohl, S. (2015) 'The Power of Institutional Legacies: How Nineteenth-Century Housing Associations Shaped Twentieth-Century Housing Regime Differences between Germany and the United States', European Journal of Sociology 25: 271-306.

Krause, N. (2008) Die Debatte um Studiengebühren: Systematische Rekonstruktion eines rapiden Meinungswandels. Wiesbaden: VS Verlag für Sozialwissenschaften.

Kreditanstalt für Wiederaufbau (KfW) (1998-2015) Geschäftsbericht. Frankfurt am Main: KfW.

Krippner, G.R. (2011) Capitalizing on Crisis: The Political Origins of the Rise of Finance. Cambridge, MA: Harvard University Press.

Langley, P. (2008) The Everyday Life of Global Finance: Saving and Borrowing in Anglo-America. Oxford: Oxford University Press.

Leisering, L. (2012) 'Pension Privatization in a Welfare State Environment: Socializing Private Pensions in Germany and the United Kingdom', Journal of Comparative Social Welfare 28(2): 139-51.

Logemann, J. (2012a) 'From Cradle to Bankruptcy? Credit Access and the American Welfare State', in J. Logemann (ed.) The Development of Consumer Credit in Global Perspective: Business, Regulation, and Culture, pp. 201-19. New York: Palgrave Macmillan.

Logemann, J. (2012b) Trams or Tailfins? Public and Private Prosperity in Postwar West Germany and the United States. Chicago, IL; London: University of Chicago Press.

Martin, R. (2002) Financialization of Daily Life. Philadelphia, PA: Temple University Press.

Martin, R., Rafferty, M. and Bryan, D. (2008) 'Financialization, Risk, and Labour', Competition and Change 12: 120-32.

Mertens, D. (2017) 'Putting 'Merchants of Debt' in Their Place: The Political Economy of Retail Banking and Credit-Based Financialisation in Germany', New Political Economy 22(1): 12-30.

Mettler, S. (2011) The Submerged State. How Invisible Government Policies Undermine American Democracy. Chicago, IL; London: University of Chicago Press.

Montgomerie, J. (2013) 'America's Debt Safety-Net', Public Administration 91(4): 871-88.

Morgan, I. (2009) The Age of Deficits: Presidents and Unbalanced Budgets from Jimmy Carter to George W. Bush. Lawrence, KA: University of Kansas Press.
Naczyk, M. and Palier, B. (2014) 'Feed the Beast: Finance Capitalism and the Spread of Pension Privatisation in Europe', in 26th Annual Conference of the Society for the Advancement of Socio-Economics (SASE), Chicago, IL, 10-12 July.

Niemi, J., Ramsay, I. and Whitford, W.C. (2009) Consumer Credit, Debt, and Bankruptcy: Comparative and International Perspectives. Oxford: Hart Publishing.

OECD (2009) Pensions at a Glance: Retirement-Income Systems in OECD Countries. Paris: OECD.

Ott, J.C. (2011) When Wall Street Met Main Street: The Quest for an Investors' Democracy. Cambridge, MA: Harvard University Press.

Palier, B. (ed.) (2010) A Long Goodbye to Bismarck?: The Politics of Welfare Reform in Continental Europe. Amsterdam: Amsterdam University Press.

Peters, J. (2012) 'Neoliberal Convergence in North America and Western Europe: Fiscal Austerity, Privatization, and Public Sector Reform', Review of International Political Economy 19(2): 208-35.

Pierson, P. (1994) Dismantling the Welfare State? Reagan, Thatcher, and the Politics of Retrenchment. Cambridge, MA: Cambridge University Press.

Prabhakar, R. (2009) 'The Assets Agenda and Social Policy', Social Policy and Administration 43(1): 54-69.

Prasad, M. (2012) The Land of Too Much: American Abundance and the Paradox of Poverty. Cambridge, MA: Harvard University Press.

Quinterno, J. (2012) The Great Cost Shift: How Higher Education Cuts Undermine the Future Middle Class. New York: Demos.

Rajan, R.G. (2010) Fault Lines: How Hidden Fractures Still Threaten the World Economy. Princeton, NJ: Princeton University Press.

Ronald, R. (2008) The Ideology of Home Ownership: Homeowner Societies and the Role of Housing. Basingstoke: Palgrave Macmillan.

Roubini, N. (2011) 'The Instability of Inequality', available at http://www.project-syndicate.org/commentary/ the-instability-of-inequality.

Schelkle, W. (2012) 'In the Spotlight of Crisis: How Social Policies Create, Correct, and Compensate Financial Markets', Politics \& Society 40(3): 3-8.

Schulz, G. (1988) 'Eigenheimpolitik und Eigenheimförderung im Ersten Jahrzehnt nach dem Zweiten Weltkrieg', in A. Schildt and A. Sywottek (eds) Massenwohnung und Eigenheim. Wohnungsbau und Wohnen in der Großstadt seit dem Ersten Weltkrieg, pp. 409-39. Frankfurt am Main; New York: Campus Verlag. 
Schwartz, H. (2012) 'Housing, the Welfare State, and the Global Financial Crisis: What is the Connection?', Politics \& Society 40(1): 35-58.

Schwartz, H. and Seabrooke, L. (2008) 'Varieties of Residential Capitalism in the International Political Economy: Old Welfare States and the New Politics of Housing', Comparative European Politics 6: 237-61.

Scruggs, L., Jahn, D. and Kuitto, K. (2014) 'Comparative Welfare Entitlements Data Set 2, Version 2014-03', available at $h t t p: / / c w e d 2 . o r g$.

Seeleib-Kaiser, M. (2013) 'Welfare Systems in Europe and the United States: Conservative Germany Converging toward the Liberal US Model?', The International Journal of Social Quality 3(2): 60-77.

Seeleib-Kaiser, M. (2016) 'The End of the Conservative German Welfare State Model', Social Policy and Administration 50(2): 219-40.

Sherraden, M. (ed.) (2005) Inclusion in the American Dream: Assets, Poverty, and Public Policy. Oxford; New York: Oxford University Press.

Soederberg, S. (2014) Debtfare States and the Poverty Industry: Money, Discipline and the Surplus Population. Abingdon; New York: Routledge.

SOEP (2013) SOEPmonitor 1984-2011. Zeitreihen zur Entwicklung wohnungsmarktrelevanter Indikatoren in Deutschland. Berlin: Deutsches Institut für Wirtschaftsforschung (DIW).

Stein, U. (2009) Zur Entwicklung der Sparquoten der privaten Haushalte: Eine Auswertung von Haushaltsdaten des SOEP. SOEP Papers on Multidisciplinary Panel Data Research 249. Berlin: Deutsches Institut für Wirtschaftsforschung (DIW).
Streeck, W. (2009) Re-Forming Capitalism: Institutional Change in the German Political Economy. Oxford: Oxford University Press.

Streeck, W. and Thelen, K. (2005) 'Introduction: Institutional Change in Advanced Political Economies', in W. Streeck and K. Thelen (eds) Beyond Continuity: Institutional Change in Advanced Political Economies, pp. 1-39. Oxford: Oxford University Press.

Sullivan, T.A., Warren, E. and Westbrook, J.L. (2000) The Fragile Middle Class: Americans in Debt. New Haven, CT; London: Yale University Press.

Trumbull, G. (2012) 'Credit Access and Social Welfare: The Rise of Consumer Lending in the United States and France', Politics \& Society 40(1): 9-34.

Verbraucherzentrale Bundesverband, Caritasverband, D., Kreuz, D.R. and Diakonisches Werk, E.K.D. (2005) Schuldenreport 2006. Berlin: Berliner WissenschaftsVerlag.

Vossensteyn, H., Cremonini, L., Epping, E., Laudel, G. and Leisyte, L. (2013) International Experiences with Student Financing: Tuition Fees and Student Financial Support in Perspective. Enschede: Centre for Higher Education Policy Studies (CHEPS).

Williams, J. (2006) 'Debt Education: Bad for the Young, Bad for America', Dissent 53(3): 53-9.

Zeldin, C. and Rukaniva, M. (2007) Borrowing to Stay Healthy: How Credit Card Debt Is Related to Medical Expenses. New York: Demos.

Zohlnhöfer, R. (2009) Globalisierung der Wirtschaft und finanzpolitische Anpassungsprozesse in Westeuropa. Baden-Baden: Nomos. 